\title{
Research on the Existing Challenges and Countermeasures in E-business Education among Universities' Upgraded Talents from Colleges: A Case Study of Beijing Union University
}

\author{
Shengjun Chang, Daozhi Chen* \\ Beijing Union University, Beijing 100101, China \\ *Corresponding author: Daozhi Chen, cdz@buu.edu.cn
}

\begin{abstract}
At present, there are indeed many problems in the training of upgraded talents among e-business students such as unclear training objectives and characteristics, as well as the lack of classified guidance and its corresponding mechanism. Therefore, there is a need for optimization and upgrading of faculties in which active research should be conducted on these issues. Through various measures to counter the challenges faced in the training of upgraded talents in e-business education based on the student-oriented ideology and advantages of universities, the environment needs to be constantly optimized while improving their levels, designing effective countermeasures, and having firm ideological beliefs. This article strives to educate senior e-business innovative talents in line with the needs of enterprises, continuously promote the integration of industry and education, as well as commit to contributing toward a comprehensive and healthy development of the e-business industry as well as social progress.
\end{abstract}

Keywords: E-business for universities' upgraded talents from colleges; Challenges and countermeasures; Beijing Union University

Publication date: June 2021; Online publication: June 30, 2021

\section{Basic characteristics of the training mode in universities' e-business upgraded talents from colleges} "Talents training mode" is the whole course system, teaching content, teaching management system, teaching evaluation, and the process of implementing the education of professional talents. It also denotes the training objectives and specifications of talents as well as the methods or means to achieve these training objectives. The higher vocational education in Beijing Union University implements a separate class teaching mode which imitates the talent training mode of normal undergraduate education. It takes into account the characteristics of e-business, the link between higher vocational education stage and college stage, as well as their respective training patterns. On the basis of highlighting application skills as well as vocational and technical skills, the emphasis is on the improvement of theory, practice, and comprehensive professional skills of undergraduate e-business talents. From this point of view, the basic characteristics of e-business upgraded talents training in Beijing Union University are discussed below.

\subsection{Employment orientation and job position}

Beijing Union University's e-business upgraded talent training is for internet or e-business enterprises, government agencies at all levels, administrative institutions, and various enterprises in Beijing. In line with the training pathway, graduates would venture into network information maintenance and editing, 
website operation and management, internet marketing and promotion, business data analysis, website design and development, customer relationship management, etc.

\subsection{Training objectives}

Beijing Union University's e-business upgraded talent training educates highly skilled talents in humanities, professional ethics, and social responsibility. These talents would be able to use the internet and information tools for internet editing, website operation, product operation, new media operation, e-business, internet marketing, promotion in various internet fields, etc.

\section{Challenges in the training of universities' upgraded talents from colleges in e-business}

By the end of 2020, 592 colleges and universities across the country have established courses for e-business and have produced a large number of professional talents for the industry. However, there are still two challenges. One of it is the lack of universities that offer e-business specialty while the other one is that there is no clear-cut master's degree in e-business among the 47 professional master's degree institutions in China. From the outcomes of e-business education to the wide strides of the development among ebusiness professionals in the industry, there are still huge gaps. The rapid development and changes in the industry resulting in various working characteristics such as high efficiency, large intensity, and stressful environments increases the requirements for e-business professionals. The talent gaps between universities and the industry are gradually widening. Therefore, it is extremely urgent to train practical, scientific, and artistic high-level e-business talents to adapt to the requirements of this era, industry characteristics, and the development of enterprises.

\section{Analysis of the challenges in the training of Beijing Union University's upgraded talents from colleges in e-business}

\subsection{Short education period, relatively complex source of students, and significant differences in professional knowledge structure}

The education period of Beijing Union University's e-business course is two years for upgraded students from colleges. Compared to the four-year e-business undergraduate program and the three-year e-business vocational period, the education period for this group of students is rather short. In the two-year education period, the whole process needs to be carried out including basic quality education, professional skills training, practical skills training, second classroom learning, and graduation assay which is according to the basic requirements of talents education to obtain a bachelor's degree in e-business. The source of students is relatively complex in Beijing Union University's e-business upgraded talent training. Upgraded students have related or similar majors from various vocational colleges in Beijing. Due to apparent differences in their previous education where different vocational colleges have varying professional curriculum system, training targets, and training paths, they intensify the difficulties faced in the university stage in regard to education, teaching organization, and learning for students. There are a few upgraded students with outstanding professional levels but their overall level of knowledge structure varies in addition to a relatively weak basic knowledge compared with normal undergraduate students. Upgraded students emphasize on the practical aspects and skills competition during the vocational education stage while their reserve of theoretical knowledge is limited. Hence, there are difficulties in theoretical training, logic training, academic thinking training, and their acceptance for new knowledge. 


\subsection{Unreasonable curriculum setting for e-business major}

Due to unclear education objectives, short education period, and the process requirements, many universities do not have a reasonable curriculum setting for upgraded e-business major, hence, they are unable to meet the requirements of the industry development. The main courses are basic general courses including management, economics, marketing, logistics management, international trade, etc. while specialized courses include database technology in e-business, website design, internet security, electronic payment, etc. This combination of basic and specialized courses may be suitable for other economic management majors but on the contrary, since e-business is a discipline which requires a strong sense of the current era and a high frequency of knowledge updates, this curriculum does not fit. At present, many traditional enterprises are undergoing information transformation and have started to be involved in the ebusiness sector. In addition to that, new e-business models such as group purchase, post-consumption purchase, installment consumption, and online payment have emerged and the requirements for e-business talents are also constantly rising. The existing talent training program lacks in terms of outdated information and a single objective which results in a disconnection between the students' acquired e-business knowledge from classes and the market demands which makes it difficult for them to meet the requirements of enterprises.

\subsection{Imbalance in the e-business faculty}

E-business is an emerging multi-discipline sector which integrates computer science, economics, management, and other disciplines. At present, most universities in China only offer master's degree and doctoral degree for information management or business administration. However, practically none of their universities offer specialized master's or doctoral education in e-business. As an interdisciplinary subject of information science and management science, it is an embarrassment that the e-business education cannot be developed even with much attention from the academia. In majority of the universities, e-business professional teachers are only focused on e-business research or they have similar majors during their master's or doctorate education but they are not trained specifically for e-business. In view of the professional teachers' growth curve, the e-business faculty is particularly lacking.

In addition, many e-business teachers in universities are lacking enterprise and commercial trainings. Moreover, the professional experiment and training laboratories in many universities are not as good as those in vocational colleges. All these will lead to students' poor learning outcomes which is not conducive to the training of talents in e-business.

\section{Analysis of countermeasures}

Facing the challenges in the education of upgraded talents of e-business, a thorough summary and analysis is performed based on experiences in the establishment of the e-business major at Beijing Union University to solve issues through representative and targeted ways in the education of universities' upgraded talents from colleges in e-business.

\subsection{Define training objectives, enhance the concept of "university-enterprise cooperation and project-driven" with the integration of industry and education, as well as continuously optimize the curriculum system}

The establishment of the e-business major in Beijing Union University was initiated in 1999 and it introduced the training direction of "university-enterprise cooperation and project-driven" in China. After 20 years, the e-business major from the same university has made great efforts to follow the geographical advantages of Beijing and through the "university-enterprise cooperation and project-driven" concept, it 
has won more than 100 awards in provincial and ministerial professional competitions in addition to 17 national awards such as the E-business Three-Innovation Competition. The e-business practice platform combines teaching activities, enterprises' production, academic research, and market development, hence achieving deep integration of the industry and education. The curriculum system is constantly upgraded along with the integration of industry and education. The system is built according to its needs and their goals are constantly refined and optimized. Breaking down the indicators, the knowledge system is effectively built and the curriculum is formed which brings scientific and practical knowledge that are closely related to the market needs to the students.

According to the research on Beijing's internet or e-business enterprises' distribution, job responsibilities, and working process, the required skills and qualities of e-business professionals are summarized and fine-tuned. Then, based on the education and achievements in career and specialty of ebusiness students in five years' time after their graduation, the objectives of talent education are determined. According to these training objectives, the graduation requirements are determined and then, they are broken down and refined into implementable, evaluable, logical, and professional indicators. Graduation requirements not only guarantee the achievement of training objectives, but they also form the basis for developing knowledge structure, forming curriculum system, and carrying out teaching activities.

Based on the concept of outcome-based education, by adopting the top-down and bottom-up methods, the improvement of professional knowledge, professional skills training, and the quality of the education are used as the main target while the methods used are based on the industry requirements. The working process is used to design the course system and course contents, align the training objectives for each course, integrate course modules, as well as the final integration of education objectives in this major.

\subsection{Enriching the second classroom, classifying students' needs, and creating an entrepreneurial and employment-oriented mechanism}

With the building of three platforms which are basic quality education, professional skills training, and practical skills training, the second classroom is constantly enriched to make up for the short training period of upgraded students. The development of the second classroom should reflect the comprehensive cultivation of professional interest, general skills, core competence, and practical working skills. It should closely focus on the "interest cultivation and professional skills cultivation" to jointly achieve the training goal of upgraded talents of the e-business major.

The effective demand analysis involves the compilation of students' files according to their entrepreneurial intention, employment demands, and interests to further their studies to guide them in the various choices of talent output. For instance, Beijing Union University has set up business incubators, students employment guidance centers, students' social practices, scientific research center, etc. and each component is equipped with their team of guiding teachers and service guides. In addition to that, links for students have been enhanced such as publicity, sharing, training, training competition, and simulation competition in the effort to encourage all students to actively participate in competitions such as the Internet Plus Competition, E-business “Three Creations" Competition, College Students Challenge Cup, and others. These methods are conducive to the training of upgraded talents in e-business.

\subsection{Optimizing the e-business faculty}

Strong teaching plans under the guidance of "going out and bringing in" promote the cultivation of "double type" teachers from the existing e-business professional teachers. An inclusive faculty with high academiclevels and rich practical experiences would be built with clear research directions winged with enterprise practices to seek deeper domains, increasing the communication between professional faculties and highly 
skilled talents of e-business industry enterprises, as well as encouraging advanced e-business specialized personnel as part-time teachers in universities. Supports are continuously provided while seeking opportunities to increase the cooperation between industry, education, and research, as well as the upgrading of the construction of e-business faculty to a strategic level.

\section{Funding}

Supported by Research on the Presence of Online Education under the Mobile Internet Background of Beijing Young Teacher Project (Project No. :12205561110-506).

\section{Disclosure statement}

The author declares no conflict of interest. 